\title{
PSYCHOLOGICAL APPLICATIONS IN PSYCHIATRY
}

Edited by Brendan P. Bradley, \& Chris Thompson

This edited volume is a review of psychological processes and research, relevant to psychiatric practice with a cognitive and behavioural orientation which reflects current trends in clinical psychology. The contributors, all psychologists, have each written about the psychology of an area which roughly corresponds to a psychiatric condition or problem area - thus the psychology which is most appropriate to psychiatric practice has been brought to the forefront.

0471907901 Dec'85 272pp $\$ 20.90 / \$ 36.80$

\section{ANTIDEPRESSANTS AND RECEPTOR FUNCTION CIBA FOUNDATION SYMPOSIUM 123}

Chairman: D.L. Murphy, National Institute of Mental Health, Bethesda, USA

Depression is a common form of psychiatric disorder which can, in severe cases, be seriously debilitating. A number of drugs have been identified which reduce the symptoms of clinical depression, and it is obviously important to discover why these antidepressant drugs are effective This symposium brings together an international group of experts in various fields to discuss the mechanism of action of antidepressants. Topics include the interactions between antidepressants and various receptor sites inside and outside the brain, animal models for the study of depression, and possible similarities between the action of antidepressants and electroconvulsive therapy (ECT).

$0471910899 \quad$ Oct'86 320pp $\$ 27.50 / \$ 47.50$

\section{THE PSYCHOSOMATIC}

APPROACH: Contemporary Practice of Whole Person Care

Edited by Margaret J. Christie \& Peter G. Mellett

There is currently a growing concern with approaches to whole-person care - this volume offers an overview of several significant developments with a form of presentation which facilitates communication and understanding at the interface of psychology and medicine. The authors have the ability to communicate across disciplinary boundaries and their chapters reflect contemporary practice of holistic care in several areas of clinical activity, for example, obstetrics, primary care, eating disorder, cardiovascular dysfunction etc.

$0471903701 \quad$ April'86 464pp $\$ 32.50 / \$ 57.20$

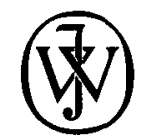

John Wiley \& Sons Ltd

Baffins Lane, Chichester, Sussex PO19 IUD 


\section{NEW Videatapes \\ Seminars in Behavioural Psychotherapy Presented by DAVID GOLDBERG}

A set of two tapes illustrating the work of three behavioural psychotherapists, John Cobb, Shirley Mercer, and Nagy Bishay. Between them they provide a set of four suggested teaching seminars. They include role-plays with commentaries, discussion points, and exercises which have been successfully used in the Department of Psychiatry and which can be easily adapted by course teachers for group or individual viewing.

Part I and Part II 40-60 minutes colour notes

VHS Part I $£ 85.00+£ 12.75$ VAT $=£ 97.75$

Part II $£ 85.00+£ 12.75$ VAT $=£ 97.75$

Parts I and II $£ 145.00+£ 21.75$ VAT $=£ 166.75$ from TAVISTOCK

Problem based interviewing in General Practice Presented by ART LESSER

This tape was made at Manchester by the Canadian psychiatrist Art Lesser to illustrate his work in teaching interviewing skills to trainee general practitioners. The aim is to help students identify and treat underlying problems which cause patients to come to their surgeries and which may be masked by an apparently straightforward complaint. He suggests how to look for verbal and visual clues and presents a model for problem sensing, detection, description, assessment. treatment, and evaluation.

55 minutes colour notes VHS $£ 85.00$

$+£ 12.75$ VAT $=£ 97.75$

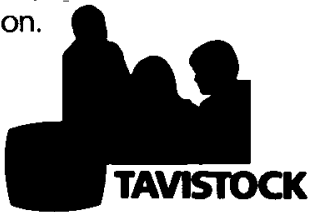

11 New Fetter Lane, London EC4P 4EE

Write and ask for more information about our videotapes 


\section{NOTES FOR CONTRIBUTORS}

PA PERS Papers for publication should be addressed to the Editor, Professor Michael Shepherd, Institute of Psychiatry, De Crespigny Park, Denmark Hill, London SE5 8AF. Contributors should send at least three copies of the text, tables, and figures. Copies other than the first may be xeroxed. The S.I. system should be adopted for text and figures. A short synopsis of about 50 words should be provided at the beginning of each article. Foreign quotations and phrases should be followed by a translation. If necessary, guidelines for statistical presentation may be found in: Altman, $D$. G., Gore, S. M., Gardner, M. J. \& Pocock, S. J. (1983). Statistical guidelines for contributors to medical journals. British Medical Journal 286, 1489-1493.

Submission of a paper will be held to imply that it contains original work that has not been previously published and that it is not being submitted for publication elsewhere.

In addition to longer articles, the Editor is prepared to accept preliminary and brief communications of between 1500 and 2500 words.

Manuscripts must be typewritten on one side of the paper in double-spacing with wide margins. The following information must be given on a single separate sheet: (1) title and short title for running head (not more than 100 characters); (2) authors' names, and (3) department in which work was done. Footnotes on the same sheet should list: (i) the authors' present addresses if different from departments in which work was done; (ii) name and address of the author to whom correspondence should be addressed; (iii) receipt of grants. Authors who would like a reprint address to be printed should include this on their manuscript.

REFERENCES (1) In the text these should follow the Harvard system - that is, name followed by date: Brown (1970). If there are more than two authors the first author's name followed by et al. should be used, even the first time that the reference appears. (2) The list of references should be typed in alphabetical order on a separate sheet and should appear as follows: Brown, J., Williams, E. \& Wright, H. (1970). Treatment of heroin addiction. Psychological Medicine 1, 134-136. Journal titles should be given in full.

Books should be cited as follows: Brown, J. (1970). Psychiatric Research. Smith: Glasgow.

ILLUSTRATIONS Only essential figures and tables should be included. Photographs Unmounted photographs on glossy paper should be provided. Magnification scales, if necessary, should be lettered on these. Where possible, prints should be trimmed to column width (i.e. $70 \mathrm{~mm}$ ). Diagrams These will usually be reduced to $70 \mathrm{~mm}$ wide. Lettering should be in either Letraset or stencil, and care should be taken that lettering and symbols are of comparable size. Illustrations should not be inserted in the text, they should be marked on the back with figure numbers, title of paper, and name of author. All photographs, graphs, and diagrams should be referred to as figures and should be numbered consecutively in the text in Arabic numerals. The legends for illustrations should be typed on a separate sheet. Tables Tables should be numbered consecutively in the text in Arabic numerals and each typed on a separate sheet.

PROOFS AND OFFPRINTS Page proofs will be sent to the senior author. Corrections other than printer's errors may be charged to the author. Fifty offprints of each paper are supplied free; additional offprints are available according to a scale of charges if they are ordered when the proof is returned.

Indexed in Current Contents

(C) Cambridge University Press 1987

CAMBRIDGE UNIVERSITY PRESS

The Pitt Building, Trumpington Street, Cambridge CB2 1RP

32 East 57th Street, New York, NY 10022, USA

10 Stamford Road, Oakleigh, Melbourne 3166, Australia

Printed in Great Britain by the University Press, Cambridge 


\section{Psychological Medicine}

Volume 17 Number 1 February 1987

\section{CONTENTS}

EDITORI ALS

Prediction of the course and outcome

of depression A. JABLENSKY page 1

The concept of disease in psychiatry

H. HÄFNER

Problems in the classification of

personality disorder P. TYRER AND

B. FERGUSON

KEMP, S. AND WILLIAMS, $K$.

Demonic possession and mental

disorder in medieval and early

modern Europe

BALL, R., HOWLETT, T., SILVERSTONE, T. 31

AND REES, L. The interrelationship

of beta endorphin, ACTH and

cortisol in depressive illness: a

controlled study

SINGH, M. M., KAY, S. R. AND OPLER,

L. A. Anticholinergic-neuroleptic antagonism in terms of positive and negative symptoms of schizophrenia: implications for psychobiological subtyping

LIDDLE, P. F. Schizophrenic syndromes, cognitive performance and neurological dysfunction

FALLOON, I. R. H., MCGILL, C. W., BOYD, J. L. AND PEDERSON, J. Family management in the prevention of morbidity of schizophrenia: social outcome of a two-year longitudinal study

ELSASS, L. AND KINSElla, G. Social interaction following severe closed head injury

O'CONNOR, N. AND HERMELIN, B. Visual and graphic abilities of the idiot savant artist

ALLOWAY, R. AND BEBBINGTON, P. The buffer theory of social support - a review of the literature

WESSELY, s. Mass hysteria: two syndromes?

TAYLOR, E., SCHACHAR, R., THORLEY, G., WIESELBERG, H. M., EVERITT, B. AND RUTTER, M. Which boys respond to stimulant medication? A controlled trial of methylphenidate in boys with disruptive behaviour

BRAND, N. AND JOLLES, J.

Information processing in depression and anxiety

KATZ, R. AND MCGUFFIN, P.

Neuroticism in familial depression
HARR IS, T., BROWN, G. W. AND

BIFULCO, A. Loss of parent in childhood and adult psychiatric disorder: the role of social class position and premarital pregnancy

HONG, B. A., SMITH, M. D., ROBSON, A. M. 185

AND WETZEL, R. D. Depressive

15 symptomatology and treatment in

21. patients with end-stage renal disease

A RO, H. Life stress and psychosomatic symptoms among 14 to 16-year old Finnish adolescents

TOUSIGNANT, M., BROSSEAU, R. AND TREMBLAY, L. Sex biases in mental health scales: do women tend to report less serious symptoms and confide more than men?

BRAITHWAITE, V. A. The Scale of Emotional Arousability: bridging the gap between the neuroticism construct and its measurement

VÁZQUEZ-BARQUERO, J. L., DIEZ-MANRIQUE, J. F., PEÑA, C.,

ALDAMA, J., SAMANIEGO

RODRÍGUEZ, C., MENÉNDEZ ARANGO, J. AND MIRA PEIX, C. A community mental health survey in Cantabria: a general description of morbidity

PRELIMINARY COMMUNICATION Psychiatric morbidity in an Italian general practice C. BELLANTUONO, R. FIORIO, P. WILLIAMS AND P. CORTINA

BRIEF COMMUNICATION

Eating behaviour of male racing jockeys M. B. KING AND G. MEZEY BOOK REVIEWS

The Citadel of the Senses J. WA LTON Social Relationships and Cognitive

Development N. O'CONNOR

The Culture-Bound Syndromes: Folk Illnesses of Psychiatric and

Anthropologiocal Interest

R. LIT TLEWOOD

Disordered Thinking and

Schizophrenic Psychopathology

J. C. CUTTING

The Provision of Mental Health Services in Britain: The Way Ahead

J. H. HENDERSON

Short reviews 